\title{
IDENTIFICATION OF TRADITIONAL FOOD RECIPES OF SRI LANKA
}

\author{
R. Abeywardhana ${ }^{1}$ and A.N.F. Perera ${ }^{2}$ \\ Post Graduate Institute of Agriculture, \\ University of Peradeniya, Peradeniya, Sri Lanka. \\ ${ }^{2}$ Wayamba University of Sri Lanka, Kuliyapitiya, Sri Lanka.
}

\begin{abstract}
Traditional food items are, made from locally available resources and culturally accepted. A study was conducted to identify traiditional food recipes and their characteristics. Two hundred different traditional food recipes were identified by using a questionnaire. 139 different plant species and 7 animal species were used to prepare these recipes. Leaves (45\%) and fruits (26\%) were the commonly used plant parts in the recipes. Knowledge about $87 \%$ of the recipes had been obtained from relatives of the present and past generations. Out of 200 traditional food recipes 76 (38\%) and 56 (28\%) recipes belong to curries and "mallum" respectively. Highest percentage (56\%) of traditional food recipes were consumd the same day. Special local preparations such as "Kurukkal", "Hathmaluwa", "Kayan hodda", "Panie gruel", "Kiri gruel" and "Thambum curry" were also identified as recipes, prepared for special cultural events, diseases, preservation and special persons. Recommended. Cost of a traditional meal to suite Dietary Allowances (RDA) energy, protein, Ca and P was Rs.87.23, Rs.16.63, Rs.109.25 and Rs.28.53, whereas for modern meal it was Rs.109.58, Rs.103.24, and Rs. 101.88 Rs. 54.58 per person respectively. The popularization of traditional food ensures a low cost balance diet with the supply of additional nutrients to humans.
\end{abstract}

Key words: Indigenous knowledge, natural resources, nutrition, traditional food items

\section{INTRODUCTION}

All humans and animal live on food. People have used large number of different foods and recipes since ancient times. It was clear that 32 traditional dishes of foods were used in alms giving for tooth relic in temple of tooth in Kandy.

Traditional food items (TFIs) can be defined as the food from a particular culture made from locally available resources and culturally accepted. It includes socio-cultural means, acquisition/processing techniques use composition and nutritional consequences for people using the food (Harriet et al, 2006). Those traditional food crops are easily found in forest, home gardens, marshy lands and seasonal tank bed arcas as natural 
At present, Sri Lanka as well as many other countries has been faced food security problem. Real food security relies on the diversity of food crops. Out of 80000 edible plants explored by man since the beginning of civilization only about 150 species have so far been explored considerably. To day less than 30 plants species meet about $90 \%$ of the world food requirement (Mal, 1994). In Sri Lanka, Ministry of Agriculture has identified 21 vegetable varieties and 12 fruit varieties availability for food through out the year (Rajapaksha, 1998). In 2004, Sri Lanka had recorded 4.2 million undernourished people (FAO, 2004). The malnutrition is resulted from food insecurity at household level. TFIs rich in vitamins, minerals and fiber. There are important foods items which the villagers prepare with plants and leaves as part of the rituals of daily life. These include the taking of herbal gruel in the morning and herbal tea between meals. This traditional habit is said to have ensured the health of Sri Lankan in ancient times (Pilapitiya, 1995).

Traditional food varieties can be effectively used as low cost food sources for low income groups of under developed countries such as Sri Lanka. About 70\% of Sri Lankan still lives in rural areas. TFIs play a very significant role of the livelihood of rural pcople in the dry zone of Sri Lanka. (Bandarathilaka, 1995). Traditional food varieties adapt well to unfavorable environment conditions and some of them can even be grown in marginal lands which have resist to pest and diseases. 'They can be used as plant genetic material to be used in future crop improvement programme.

There is valuable indigenous knowledge associated with cultivation, preparation, nutrition and storage of traditional food varieties. This knowledge has been passed generation to generation since ancient times. But today our TFIs faced in danger due to various reasons. Our traditional subsistence agriculture, farming systems, food systems and food culture were challenged for the first time during the British era, in the $19^{\text {th }}$ centenary. As a result of promotion of plantation agriculture, traditional agriculture suffered.

The green revolution launched in the 1960 s had as its motto the increase in productivity using high yielding varieties and high inputs. As a result of cultivation of selected varieties of a few cash or market oriented crops, thousand of food crops grown in farmers' fields have been seriously threatened. In 1900 Sri Lanka have $70 \%$ cover of forest land. But in year 2001 we have $22.4 \%$ of forest cover (Anon, 2001). Deforestation has also a serious impact on plant genetic erosion and food security of the local people.

Therefore, this study was undertaken to collect information about TFIs and their recipes of Sri Lanka. As well as identification of conservation methods and sustainable management of this natural resource will be discussed and analyzed via this study. This workout the cost comparison of traditional meal and modern meal which fulfill the recommended dietary allowances. Conservation of TFIs and their recipes are also discussed to uplift the food security of Sri Lanka. 


\section{MATERIALS AND METHODS}

A study was conducted to identify traditional food recipes and their characteristics. Two hundred different traditional food recipes were identified by using a questionnaire from Kandy, Matale, Nuwara Eliya, Kurunagala, Polonnaruwa, Monaragala, Gampaha and Ratnapura district. Purposive sampling method was used to identify relevant respondents. Meanwhile in depth discussions and some observations of preparing traditional food recipes were carried out with respondents. Current market prices were used to estimate costs of the typical traditional and modern meal. All cost calculations and charts were prepared by using MS-Excel. Secondary data such as nutritional values of both meals and recommended dietary allowances were obtained from books, journals and via internet.

\section{RESULTS AND DISCUSSION}

\section{a) Characteristics of traditional food recipes}

\section{Different plant parts used for traditional food recipes}

The study revealed that 139 plant species used for preparing traditional food recipes. Highest percentage (45\%) of traditional food recipes were prepared by using green leaves. Being a tropical country Sri Lanka has large diversity of evergreen plants. People can harvest edible leaves from those plants throughout the year. As well as this plant part that leafy vegetables provide protective function in supplementary a variety of essential nutrients (Oomen and Grubben, 1977). Large numbers of leafy vegetables were collected to prepare salads, curries and mallum to add taste to rice dishes that eaten as main meals (Pathirana, 2004). Naturally grown edible leaves were harvested from home gardens, chena, stream banks, shrub jungles and fallo: paddy fields.

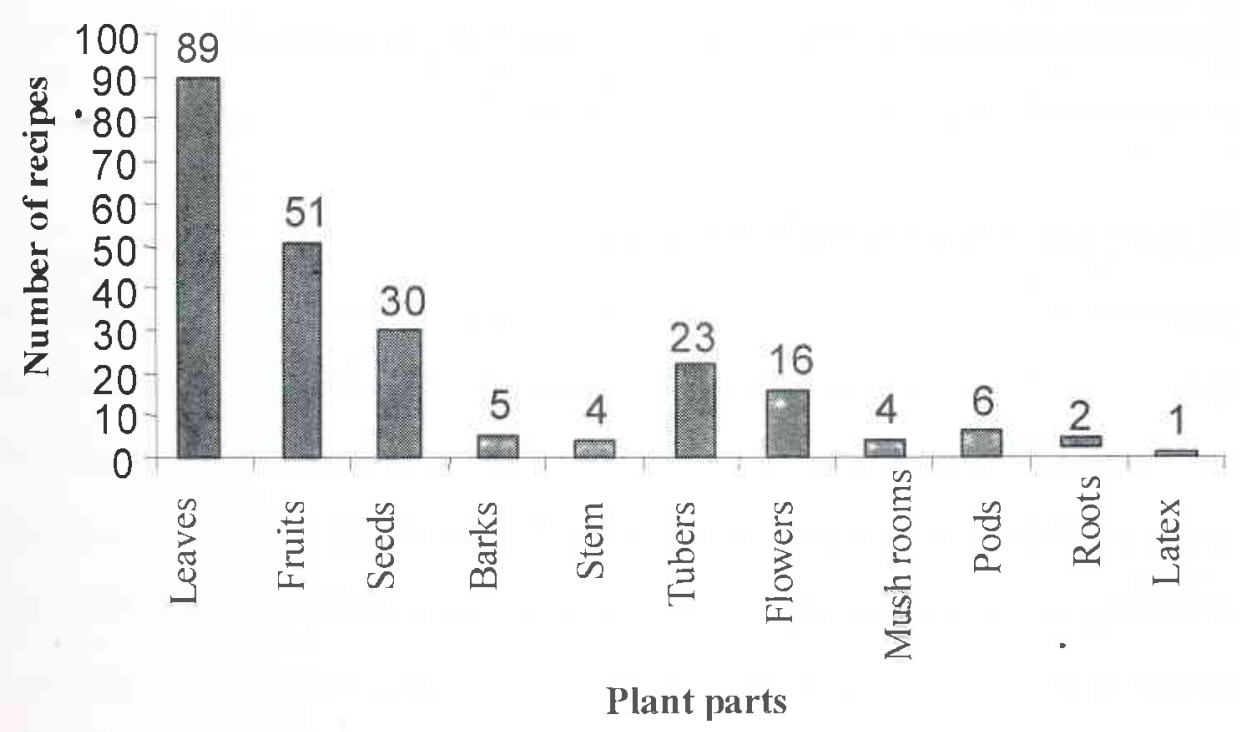

Figure 1: Different plants used for preparing traditional food recipes 


\section{Methods of obtaining traditional knowledge}

Knowledge of preparation and their medicinal value of traditional food recipes were transferred from ancestors $(87 \%)$. The knowledge which gained through books was $2 \%$. The knowledge was being transmitted from elder people to younger people in the community. None of their experience has been based on scientific experience, but strengthened through trial and error (Wickramasinghe, 1993). This was enhanced the conservation of this valuable human capital for future generation.

\section{Food storing time of traditional food recipes}

Highest percentage (56\%) of traditional food recipes were consumed on the same day. $20 \%$ and $10 \%$ of recipes were stored 1 day and 2 day respectively. Being majority of traditional food items were harvested from surrounding areas people did not want to store recipes. But some seasonal traditional food items were preserved and stored for future consumption. The closer vegetables and fruits are grown to the consumer, the more likely that local produce will be fresh and have higher nutrient content. During storage and transport, the level of Vitamin C is reduced (Anon, $2000 \mathrm{a}$ ).

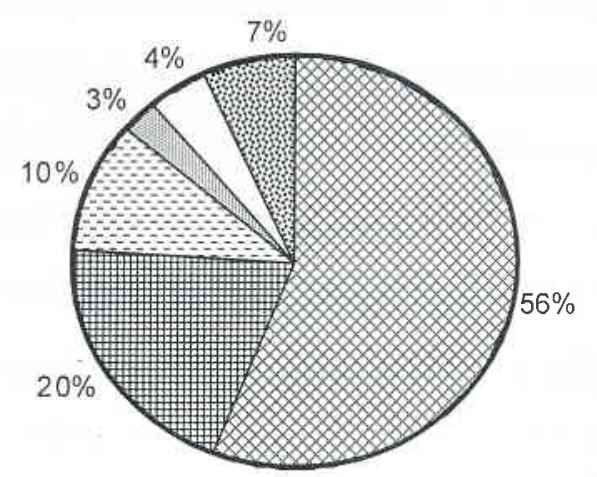
图 $<$ day
曲 1 day
- 2 days
北 1 Week
$\square 1$ month
国>1 month

Figure 2. Food storing time of traditional food recipes

Wild meat, fish, different kind of seeds and flour were stored more than one month. Most common methods of food preservation were sun drying, smoking and dehydration.

\section{Identified different types of traditional food recipes}

Out of 200 traditional food recipes $76(38 \%)$ and $56(28 \%)$ recipes belong to curries and "mallum" respectively. Both type of traditional food recipes were consumed in main meals i.e. breakfast, lunch and dinner. "Roti", "Pittu", "Thalapa" and "Dhohi" were considered as whole food and consumed in breakfast and dinner. A same study carried out in Uva province of Sri Lanka, out of 192 traditional food recipes, 107 $(56 \%)$ recipes were belong to curries and "mallum" (Aththanayaka, 2006). Herbal gruel is a kind of porridge made of cereals mainly raw rice, and coconut milk as the liquid, with leafy vegetables. It is not generally prescribed as a healing medicine, but it is considered an imporlant part of the morning meal (Fernando, 1999). Wild meat, fish, some fruits and flour were preserved for future consumption. 


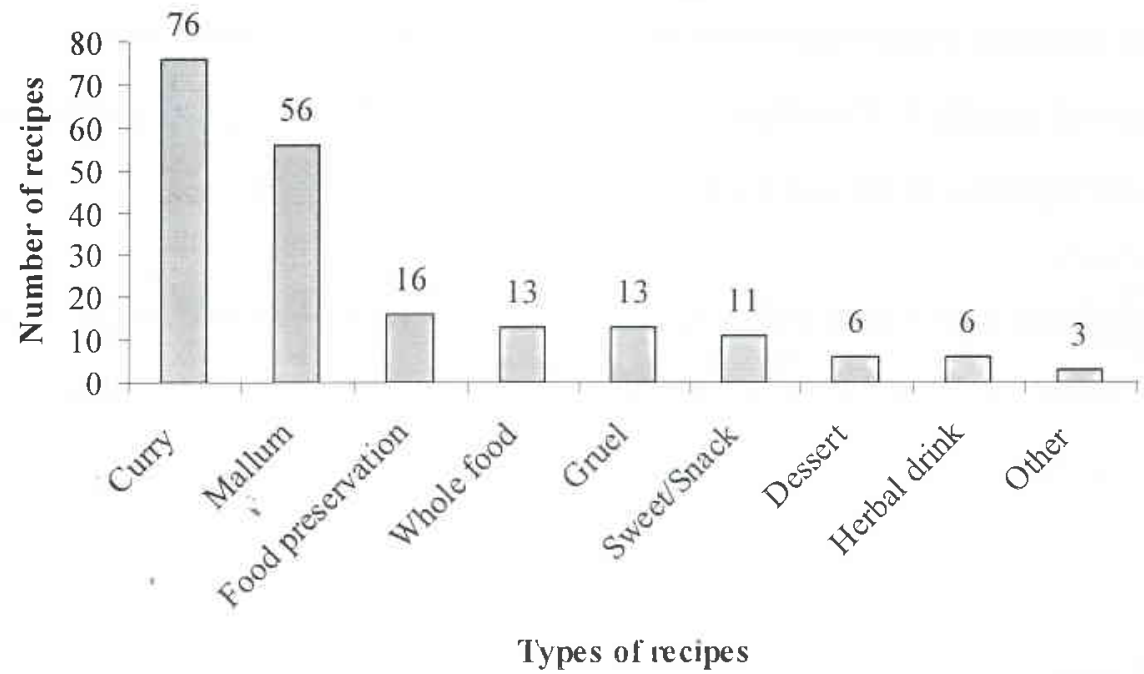

Figure 3. Identified different types of traditional food recipes

\section{Cost comparison of a traditional meal and modern meal}

The study was worked out cost of energy and nutricnts with respect to recommended dietary allowances for a traditional meal and modern meal. 'I his typical traditional meal was included traditional food items such as rice (raw) Sesbenia leaves, immature jak fruit (Polos), green gram curry, jak seed (Kalupol maluwa) and one banana (Amban). Typical modern meal was consisted with rice (white), bean curry, carrot curry, potato curry, chicken and a glass of milk. Recommended dietary allowances for energy, protein, calcium and phosphorous were $2530 \mathrm{kcal}, 57 \mathrm{~g}, 750 \mathrm{mg}$ and $500 \mathrm{mg}$ per day respectively (Anon,2000: Anon,2002: Wickramanayake, 2002).

Table 1. Nutrient composition, Nutrients per unit cost and market prices of typical traditional meal and modern meal

\begin{tabular}{|c|c|c|c|c|}
\hline \multirow[b]{2}{*}{ Component } & \multicolumn{2}{|c|}{ Typical traditional meal } & \multicolumn{2}{|c|}{ Typical modern meal } \\
\hline & $\begin{array}{l}\text { Nutrient } \\
\text { compositions }\end{array}$ & $\begin{array}{l}\text { Nutrients } \\
\text { per unit } \\
\text { cost (Rs.) }\end{array}$ & $\begin{array}{l}\text { Nutrient } \\
\text { compositions }\end{array}$ & $\begin{array}{l}\text { Nutrients } \\
\text { per unit } \\
\text { cost (Rs.) }\end{array}$ \\
\hline Energy (kcal) & 1439.7 & 29.0 & 1863.4 & 23.1 \\
\hline Protein (g) & 170.15 & 3.4 & 44.56 & 0.6 \\
\hline $\mathrm{Ca}(\mathrm{mg})$ & 340.77 & 6.9 & 594.17 & 7.4 \\
\hline $\mathrm{P}(\mathrm{mg})$ & 870.1 & 17.5 & 739.4 & 9.2 \\
\hline Market price (Rs/meal) & \multicolumn{2}{|c|}{49.64} & \multicolumn{2}{|c|}{80.71} \\
\hline
\end{tabular}


Collective energy and nutrients values that given by each ingredient of the typical traditional meal and modern meal were showed in table 1. Calculated current market price for the typical traditional meal and the typical modern meal were Rs.49.64 and Rs.80.71 per person, respectively.

The cost of modern meal was higher than traditional meal to fulfill recommended dietary allowances for energy, protein and $\mathrm{P}$ (Table 2). To accomplish calcium requirement, cost of traditional meal was higher than modern meal by $7.23 \%$. Glass of milk component in the typical nıodern meal was provided higher $\mathrm{Ca}$ amount.

\section{Nutrient per unit cost .}

The traditional meal was provided higher energy, protein and phosperous per rupee than modern meal (Table 1). The modern meal was supplied $7.23 \%$ more Ca per rupee than the traditional meal. The traditional meal was provided recommended dietary allowances with low cost with compared to modern meal. At present $58.7 \%$ of Sri Lankan house hold income is spent for foods and beverages (Anon, 2007). The ingredients of traditional meal were collected from the natural environment without any cost by the rural people. Therefore traditional meals can be reduced the household expenditure for foods. This enhances the reduction of malnutrition in household level of low income groups of underdevelopment countries such as Sri Lanka (Rajapaksha, 1998).

Table 2. Cost of meals for requiring ecommended dictary allowances

\begin{tabular}{lcc}
\hline Component & Traditional meal(Rs/person) & Modern meal(Rs/person) \\
\hline Energy (kcal) & 87.23 & 109.58 \\
Protein (g) & 16.63 & -103.24 \\
Ca (mg) & 109.25 & 101.88 \\
P (mg) & 28.53 & 54.58 \\
\hline
\end{tabular}

a) Special local food preparations

Table 3. Special local food preparations

\begin{tabular}{|c|c|c|c|}
\hline $\begin{array}{c}\text { Name of } \\
\text { preparation }\end{array}$ & Major food ingredien ts & & $\begin{array}{l}\text { Type of } \\
\text { recipe }\end{array}$ \\
\hline Kurukkal & Mcat with fat & & Prcservation \\
\hline \multirow[t]{4}{*}{ Kayan hodda } & Piper - (Piper nigrum) & . & Medicinal \\
\hline & Goraka - (Garcinia cambogia) & & spicy soup \\
\hline & Garlic-(Allium sativum) & & \\
\hline & Cinamam - (Cinnamonum zeylanicum) & & \\
\hline
\end{tabular}


Hathmaluwa Kandy dis trict-Ududhumbara

Curry

Kiri ala - Colocasia esculenta

Papaya - Carica papcrya

Pumkin - Cucurbita moschata

Tomato-Lycopersicon esculentum

Brinjol - Solanum melongena

Snake gourd - Trichosanthes anguina

Vigna- Vigna cylindrical

Thambum Goraka-Garcinia cambogia

Medic inal

hodda . Tamarind-Tamarindus indica

spicy soup

Piper - Piper nigrum

Garlic - Allium sativum

Coriandrum- Coriandrum sativim

Ginger - Zingiber officinale

Coconut - Cocos nucifera

Kiri kedha Coconut-Cocos micifera

Gruel

Rice - Oryza sativa

Garlic - Allium sativum

Pani kedha Coconut-Cocos nucifera

Gruel

Kithul trickle - Carijota urens

Rice - Oryza sativa

Sap kanji Iramusu-Hemidesimus indicus

Herbal gruel

Hathawariya- Asparagus racemosus

Monarakudumbiya-Vernonia limerea

Gotukola-C'entella is'iatica

Ranaward-Cassia auriculata

Wal penela-Cardiospermum microcarum

Polpala - Aerva lanata

Koon

Koon - Schleichera oleosa

Preservation

Anukaya

Dhohi

Rice- Oryza sativa

Whole food

Kurakkan - Eleusine coracana

Kahipiththan Kahipiththan-Cyclea peltata

Dessert jelly

Thal kiri

Palmyrah- Borassus flabellifer

Soft drink

Coconut - Cocos micifera 
Special local preparations were identified such as, "Hathmaluwa", "Kayan hodda" (medicinal spicy soup), "Panie gruel", "Kiri gruel" and "Thambum" curry (medicinal spicy soup). Those special local preparations were prepared for special cultural events, diseases, preservation and specific persons. "Kayan hodda" and "Thambum" curry were specially prepared for pregnant mothers and stomachache patients respectively. "Hathmaluwa" was prepared by using seven edible plant ingredients. Those plint ingredients used were different from place to place. It was obvious that Sri Lanka shows the diversity food recipes. Although "Hathmaluwa" was prepared during Sinhala new year, sometimes it was prepared for ritual ceremonies. The "Hathmaluwa" and rice were provided $24 \%$ of energy, $25 \%$ of protein, and $34 \%$ of calcium requirement of pregnant woman (Anon, 2000).

\section{CONCLUSIONS}

Most of traditional food recipes are prepared by using leaves. Different varieties of leaves are used as leafy vegetables and herbal gruels. Knowledge of traditional food recipes is transfurred from generation to generation. Being majority of traditional food items ware harvested from surrounding areas people did not want to store recipes. But some seasonal traditional food items were preserved and stored for future consumption. Curry and mallum were most frequently prepared recipes by using traditional food items. Recommended dietary allowances of energy, protein and phosperous can be fulfilled from traditional foods with low cost than modern foods.

Although edible plants are available in the environment lack of knowledge of identification and preparation of traditional food items may be caused to underutilize this natural resource. Sờme social attitudes were negatively affected to the usage of traditional food items. To overcome those issues education and awareness programmes of exploitation and preparation of traditional food varieties are essential. The popularization of traditional food items should be needed to food security of nation and low cost balance diet for people while manåging the natural resources.

\section{ACKNOWLEDGEMENTS}

Authors are grateful to Mr. Lalith Wegethunga, Ms. Sujani Wegethunga, Mr. Sanjaya Perera, and Ms. Neela Rathnayake for their assistance to carry out the survey in Hasalaka and-Matale Divisional Secretariat divisions. Authors would also like to thank all respondents who provided their knowledge on traditional food recipes. 


\section{REFERENCES}

Anon (2000a). Dietary Guide. CINDI-Countrywide Integrated Non Communicable Disease Intervention.

Denmark, Copenhagen, WHO, Regional Office, Europe. pp. 27-28.

Anon (2000b) Nutrition Guide. Eds: T.W. Wickramanayake, C.D.Gunarathna. Nutrition division,

Department of Health Services, Ministry of Health and Indigenous Medicine, Colombo 10. pp.38. Anon (2001) Administration report of the conservator general of forest Sri Lanka. Year 2001. Forest

Department, Ministry of Forestry and Environment. pp.59.

Anon (2002) Protein and amino acid requirements in human nutrition: Report of joint FAO/WHO, UNO expert consultation. WHO technical report series: No 935.

Anon (2007) Annual report 2007, Colombo: Central Bank of Sri Lanka.

Aththanayaka, S. (2006). Applied research on uncultivated food crops in Uva province. Bio Diversity

Research Information and Training Center. pp132-136.

Bandarathilake, H.M (1995) Use of Non-wood forest products by village communities in Sri Lanka.

Proceeding of regional expert consultation on Nov 28-Dec 02 1995. Beyond timber: Social

Economic and cultural dimensions of Non-wood forest prodıcts in Asia and Pacific. ГAO/

RAP/Bangkok. pp. 299-305.

FAO, (2004) Number of undernourished people. Available from:http://www.fao.lk (Accessed 08 Junc 2008)

Fernando, S. (1999) Herbal food and medicines in Sri Lanka. pp.115-118.

Härriet, V. K., Suttilak, S., Salome, Y., Lalita, B., Lidan and Salek A., (2006) Documenting traditional food systems of indigenous peoples: International case studies, guidelines for procedures, FAO publication, and p.19.

Mal, B. (1994) Underutilized grain legumes and pscudo cereals, their potentials in Asia. RAP publication, FAO, Bangkok.

Oomen, H.A.P.C., Grubben, G.J.H. (1977) Tropical leafy vegetables for human nutrition.

Pathirana, R.P.I.T.R., Gunasekara, T.M.C.P., and Widanapathirana, A. (2004) A study of traditional food items in Walaththewa and Galgiriyawa Grama Niladari divisions in north western province of Sri Lanka In: Proceedings of $4^{\text {th }}$ Agricultural Research Symposium, $10^{\text {th }}$ August 2004, Wayamba University of Sri Lanka,

Pilapitiya, U. (1995). Extraction of Non-timber forest production for Ayrvadic medicine in Sri Lanka.

Proceedings of regional expert consultation on Nov 28-Dec 02 1995. Beyond timber: Social, Economic and Cultural dimensions of Non-wood forest products in Asia and the pacific:

FAO/RAP/Bangkok. pp. 61-66. 
Rajapaksha, U. (1998) Traditional food plants in Sri Lanka. Hector Kobbekaduwa Agrarian Research and Training Institute. pp1-10.

Wickramanayake, T.M. (2002). Food and nutrition. Hector Kobbekaduwa Agrarian Research and Training Institute. pp 365-368.

Wickramasinghe, A., (1993). Multiple use of forest tree by the rural communities. Multipurpose tree species in Sri Lanka, Research and Development: Proceedings of regional workshop on multipurpose tree species, Kandy, Sri Lanka, 12 ${ }^{\text {th }}-14^{\text {th }}$ March, 1993 Ed: H.P.M.Gunasena. pp.180-190. 